\title{
Successes and Failures of China's Golden-Sun Program
}

\author{
Yong-hua Wang ${ }^{1, a}$, Guo-liang Luo, ${ }^{2, b}$ and Huang Kang ${ }^{3, c}$
}

\author{
School of Economics and Management, North China Electric Power University, No. 2, Beinong \\ Road, Changping District, Beijing 102206, China
}

\begin{abstract}
Keywords: Golden-Sun Program, Investment subsidy, Feed in tariff (FIT), Regulation, Grid connection

Abstract. In 2009, the Chinese government released the policy about the Golden-Sun Program, deciding to provide investors with upfront subsidies prior to project construction with the special funds for renewable energy, with the aim to accelerate large-scale industrialization of PV power generation in China. This paper suggests four indicators used to assess the success and failure of the Golden-Sun Program: policy system design, effectiveness, administrative institution and time frame/development period. The results showed that: the success of the Golden-Sun Program is: fiscal subsidies play a notable role in promoting growth of China's PV market; it significantly improves the efficiency of constructing PV power generation facilities at home and provides clean energy to residents in rural areas without access to power;management and design of distributed PV power generation are improved significantly. The failure of the Golden-Sun Program is: lack of systematic design and effective coordination in policies; institutional deficiencies in policy design; obstacles to connecting user-side PV systems to the grid; lack of effective regulation leads to poor quality.
\end{abstract}

\section{INTRODUCTION}

China's solar photovoltaics (PV) power generation started in the 1970s and entered a period of steady expansion in the middle 1990s. In the early 1990s, PV power was mainly applied in communications and industrial fields and remote areas. In 1995, more than 40 PV power stations were built at the county, township and village levels, and about 150,000 sets of household PV power supply systems were set up [1].

In 2002, the Chinese government initiated the Township Electrification Program, in a bid to provide electricity for households in villages of seven western provinces and autonomous regions without power supply by using a mixture of solar PV and small wind power. The program greatly stimulated the solar PV market, with several solar cell encapsulation lines put in place across China that resulted in the rapid increase in the annual output of solar cells. In October 2003, the State Development and Planning Commission and MOST developed the Program on Development of Solar Energy Resources in the Next Five Years, and decided to implement the Brightness Program, raising 10 billion yuan to promote application of solar power generation technologies and achieving an installed capacity of $300 \mathrm{MW}$ in nationwide solar power generation systems by 2005 [2]. In January 2006, the Renewable Energy Law of the People's Republic of China officially took effect, providing a legal basis for application of PV power generation systems at home. However, it is undeniable that China's PV application market is relatively backward with a rather small market capacity and the rapid development of the PV industry has been mainly driven by the international market.

Since 2000, Germany has taken the lead to introduce the feed-in tariff (FIT) policy mechanism, which greatly promoted expansion of its PV market. Other European countries followed the example of Germany and successively implemented the FIT mechanism, and therefore the PV market across Europe has seen a rapid growth. From 2000 to 2010, the world's PV market registered an average annual growth rate of $54.1 \%$. Thanks to the driving force from the European market,China's PV industry has developed rapidly since 2004 , with the growth rate exceeding $100 \%$ for five consecutive years. In 2007, China became the world's biggest producer of solar cells for the first time [3].

Pinched by the US financial crisis and European debt crisis, China's PV industry has seen a shrinking overseas market since 2009, making exports impeded and PV enterprises shut down. Given the economic and financial situations both at home and abroad, the Chinese government determined to 
increase policy incentives by implementing the Golden-Sun Program to accelerate the growth of the PV market at home.

China has abundant solar energy resources [4,5].The estimated technical potential for installing PV in China is up to 2070GW.Beginning in 2009, the Chinese government formulated a series of policies and regulations to encourage domestic PV deployment [6,7]. The government primarily encouraged the adoption of large-scale PV first,via upfront subsidies of up to 50-70\% under the Golden Sun Demonstration Program and PV Rooftop Subsidy Program. Several disadvantages of providing an upfront subsidy to large-scale PV, however, became apparent [8]. First, an upfront subsidy provides an incentive to install PV but does not provide a strong incentive for the systems to produce electricity, which resulted in concerns about the installation of low-quality PV projects and cheating the subsidy programs [9]. Second, the central government found the subsidies increasingly difficult to afford. Third, the policy focused on subsidizing large-scale PV systems, which resulted in installed systems-many in northwest China-being remote from demand centers, creating challenges to the transmission system and the ability to use the generated power. In addition, there is increasing concern about the water required for PV panel cleaning, especially in the dry and sandy northwest area of China [10].

At the early stage of PV market development, developed countries including Germany,USA and Japan applied the policy of initial investment subsidy as it contributes to the rapid start of the market. The 1,000-Roof Program in 1991 and the 100,000-Roof Program in 1998 carried out in Germany, and the Buy Down Program in California, with 50\% subsidy to the initial investment, are both the application of initial investment subsidy. Japan started the New Sunshine Plan in 1995 to offer 50\% subsidy to the initial investment in the first year with a progressive decrease of $10 \%$ year by year till the initial investment subsidy cancellation in 2005[11].

S. M. Moosavian et al.[12] review the policies existing and in the making in seven leading countries(Australia, Canada, China, Japan, Germany, USA, France) that actively champion use of PV. They found a variety of policies like feed-in-tariff (FIT),renewable portfolio standard(RPS), investment tax credits(ITC),pricing laws, production incentives, quota requirements, trading systems etc. have been developed and implemented to promote the use of renewable energy [13,14].These strategies have main objectives such as reducing the environmental impacts of the energy sector, reducing reliance on fossil fuels and encouraging new industrial development. The renewable portfolio standard (RPS) and the feed-in tariff(FIT) are the most popular policies until now. Although, there are a lot of debates surround their effectiveness of each one, expecting a choice that has to be made between them. For this, it could be decided by the countries that which renewable energy policy can be applicable in their own particular circumstances and objectives.

For China's policies of distributed PV,Niu Gang[15] sorts out the policy system of the distributed energy development and summarizes the main points of incentive policies. By studying policy tools for PV power generation in China, Germany and Japan,Zhu Yuzhi et al.[16] put forward that the character and applicability of policy tools is noteworthy in policy design for China's distributed PV industry.The adaptability between the policy tools and institutional environment should also be taken into account to improve the effectiveness of the policy implemented. Jiang Lin[17] references the policies in developed countries involving the feed-in tariff policy, the net metering policy, cost-sharing policy and technical regulations of grid-connected. He also proposes the grid-connected policy recommendations for the development of distributed PV power generation in Jiangsu Province. Wu Qiong et al.[18] propose that the most practical and effective policy to promote the development of China's PV industry is to improve the tariff. By comparing the FIT (feed-in tariffs) policy in Germany, Britain, Japan and the United States, Huang Haitao et al.[19] make innovative recommendations on China's price subsidies for distributed PV. Based on China's national conditions and energy strategy,Meng Xiangan[20]makes specific policy recommendations so as to achieve the goal of sustainable development of China's PV. Mandatory grid access, the full indemnification of the acquisition, tariff classification and the share of the whole grid etc are included.

As to the economic performance of distributed PV power generation, scholars have conducted a number of related researches. Gilberto de Martino Jannuzzi and Conrado Augustus de Melo[21] use a 
technology diffusion model and calculate the cost of the mechanisms to evaluate its effectiveness in Brazil. Antonio Colmenar-Santos et al.[22] analyze the profitability of the grid-connected distribute PV facilities for household electricity self-sufficiency. Lin Lihua et al.[23] establish an economic analysis model to obtain the cost of the distributed PV system. Gobind G. Pillai et al.[24] present a comparative assessment of the near-term economic benefits of grid-connected residential PV systems. Huang $\mathrm{He}[25]$ believes that the personal upfront investment cost of distributed PV power generation project of family is still high and the payback period is long.Xiao Fengjun [26] points out the operation of power system and policies of economic dispatch have great impacts on the efficiency of electricity generation. From the perspective of national economic development, Jin Qiang et al.[27] insist that the current PV power generation does not have the national economic rationality in some areas of China. By using financial analysis and risk analysis, Jiao Guanghua[28] indicates that for distributed PV projects, the social and environmental benefits are quite high.

Xingang Zhao et al.[29] review some main points of relevant policies including financial support,technology innovation and management improvement. Their study shows that the main relevant policy variables that impact on economic performance of distributed PV system are subsidies, benchmark price, electricity price and tax.

The rapid development of distributed PV system of distributed PV industry in China closely ties to the relevant policies support. In recent years, the development of renewable energy of China has attracted worldwide attention. However, renewable energy consumption still accounts for a very small proportion of the total energy consumption in China, and the total installed capacity of renewable energy power generation also account for a small proportion in the national total installed capacity[30] (see Fig.1.). This reveals the defects of China's energy development as well as related management systems and mechanisms [31,32].The fact indicates, in China, whether the relation between grid connection and the benefit of grid enterprises can be deal with affects the normal development of PV generation. The development of PV industry will decrease electricity purchase from power grid, which will harm the benefit of grid enterprise. Grid enterprises have to recover the cost of constructing power grids. Even with initial investment subsidy of the Treasury, there are still wheeling cost. Since grid enterprises are responsible for grid-connection of PV generation and installation of measure instruments, they play a significant role in the development of PV generation. At present, China's PV market launch faces following major problems: first of all, higher cost of PV generation. Let's take the distributed PV for example, it has become the policy priority of renewable energy development in China since 2012 and ambitious planning for it has been formulated and updated. In 2013 a national unified subsidy policy was put into implementation. However, the actual progress is far below expectation. By constructing the analytical framework of levelized cost of electricity (LCOE),Jiahai Yuan et al. found that under existing tariff and subsidy policies, with ideal conditions of most favorable financial arrangement and maximum annual operation hours, distributed PV projects located in regions with best solar resource or high commercial/industrial retail electricity prices are able to break even[33].Secondly, inadequate incentives of Chinese Government to grid enterprises. It happens sometimes that PV generation are not accepted in western regions. Relative distributed PV development policy have not been fully carried out. Grid enterprises have not really accepted PV generation. Thirdly, imperfect technology standards and management procedures. To sum up, in China, a management system of power system operation of adapting new energy (PV etc.) grid-connecting needs to be established, legally binding grid connection technique standards on national level needs to be enacted, technique innovation needs to be encouraged and pushed, and PV generation cost needs to be cut. 


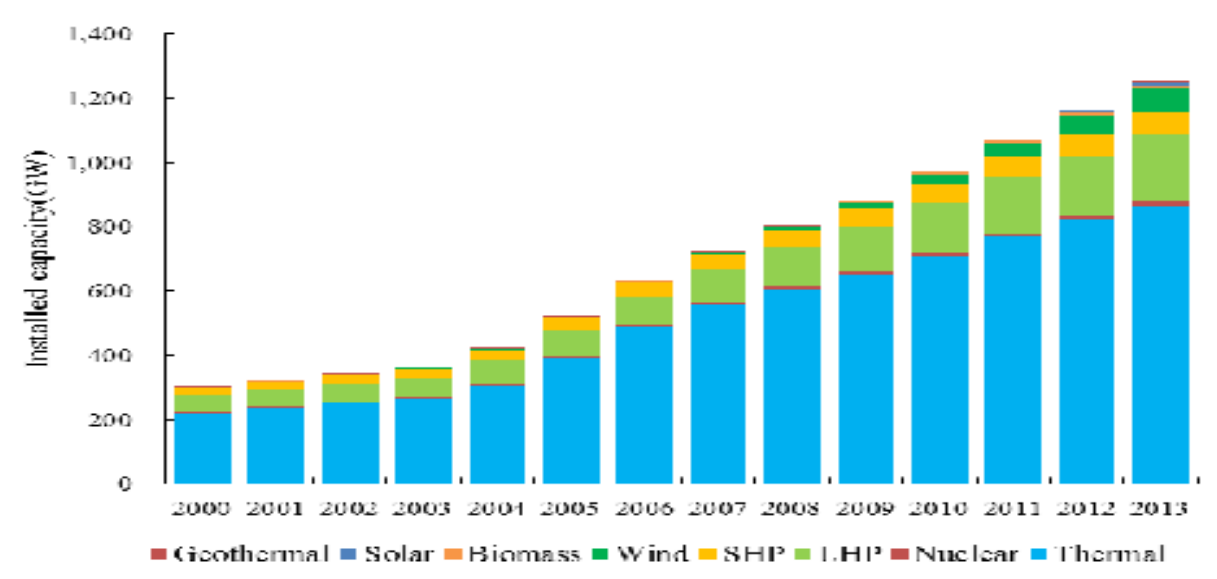

Fig.1. Growth of installed capacity of each kind of energy

The Chinese government has in recent years put in place a large number of incentive policies for distributed solar PV.However, some of these policies have not been well performed due to many constraints[34-38]. Their main incentives to boost and guarantee the industrialization and large-scale development include FIT, fiscal, taxation and financial policies(see Table 1). Though the differences in institution, policy environment, resource endowment status, technical development stage and market development level, the said countries are different in incentives(see Table 2), These academic views lay the theoretical and methodological basis for the research. 
Table 1. Comparisons of solar PV Incentives of China, USA, Germany and Japan

\begin{tabular}{|c|c|}
\hline Countries & Main incentives \\
\hline China & $\begin{array}{l}\text {-Initial investment subsidy: Golden Sun Project offers subsidies of } 50-70 \% \text { of the total investment. } \\
\text { - FIT (feed-In tariff): In August } 2013, \text { National Development and Reform Commission stated that the } \\
\text { benchmark on-grid prices were } 0.9 y u a n / \mathrm{kW}, 0.95 y \text { yan } / \mathrm{kW} \text { and } 1.0 \mathrm{yuan} / \mathrm{kW} \text { for three regions respectively } \\
\text { based on the solar energy conditions and PV generation station's resource and construction costs, offered a } \\
\text { subsidy of } 0.42 \text { yuan } / \mathrm{kW} \text { for distributed PV generation, and defined the term for the pricing and the subsidy to } \\
\text { be } 20 \text { years. } \\
\text { - Fund support: China established Renewable Energy Development Fund to support PV and other renewable } \\
\text { energy-fueled power generators In } 2013 \text {, the renewable energy-fueled electricity add-on tax standard was } \\
\text { improved to } 0.015 y u a n / \mathrm{kW} \text {. But a big gap exists between the fund support and demand. } \\
\text { - Credit policy: In July } 2013 \text {, China Development Bank offered middle- and long-term loan for distributed } \\
\text { PV demonstration zones and other large-scale projects. } \\
\text {-R\&D subsidy: None }\end{array}$ \\
\hline USA & $\begin{array}{l}\text {-Initial investment subsidy and electricity price subsidy: } 1.5-5.0 \mathrm{USD} / \mathrm{W} ; 0.05-0.46 \mathrm{USD} / \mathrm{kWh} \\
\text { - Investment tax credit (ITC): } 30 \% \text { of installation cost, to expire at the end of } 2016 \\
\text { - Renewable portfolio standard (RPS). } \\
\text { - Net-Metering: Carried out in } 43 \text { states. } \\
\text { - Credit loan: Obama Administration offers } 30-40 \text { billion USD loan guarantee for PV projects. } \\
\text { - Fund support: Funds for development of renewable energy include the energy fund of Department of } \\
\text { Energy, the renewable energy fund of Department of the Treasury and the rural energy fund of Department of } \\
\text { Agriculture. } \\
\text { - R\&D subsidy: The government offers fund to support alternative energy. Federal Energy Agency invested } \\
17 \text { million USD to PV projects headed by six major companies in } 2008 \text {. }\end{array}$ \\
\hline
\end{tabular}

Germany -FIT: According to the Renewable Energy Law Amendment enacted in April 2012, the government greatly cut PV subsidy again. The FIT enjoyed by PV projects will be progressively decreased month by month. The subsidy to electricity price will be limited to $2.5-3.5 \mathrm{GW}$ each year, and canceled for new PV projects when the total installed capacity reaches $52 \mathrm{GW}$.

-Investment tax credit (ITC): $17 \%$ value-added tax exemption for commercial PV systems, and tax equivalent of $12.5 \%-27.5 \%$ of the investment to be exempted for production and equipment manufacturers. - Credit guarantee: Encourage residents to purchase PV equipment through discount loans; preferential loans equaling to $75 \%$ of investment to grant to enterprises investing in renewable energy field is stipulated in the law.

Japan $\quad$ FIT: Government purchases PV electricity at a price three times of that in China, and carries out the policy "price subsidy as the major mode, and investment subsidy as the auxiliary mode."

- Consumer (demand side) subsidy: 50\% of the PV equipment cost to grant to residents who install the equipment on their roofs.

-R\&D subsidy: Encourage technical innovation, and offer subsidies to R\&D institutions.

Source:Compiled by authors. 
Table 2. Roles of different incentives for the PV power generation industry at various stages

\begin{tabular}{|c|c|c|c|c|c|}
\hline \multicolumn{2}{|c|}{ Incentives as policy instruments } & \multicolumn{4}{|c|}{$\begin{array}{c}\text { Technical and commercial development stages of the PV power generation } \\
\text { industry }\end{array}$} \\
\hline & & $\begin{array}{l}\text { Technology } \\
\text { R\&D }\end{array}$ & $\begin{array}{l}\text { Project } \\
\text { demonstration }\end{array}$ & Expansion stage & Maturity stage \\
\hline \multirow{5}{*}{$\begin{array}{l}\text { Fiscal } \\
\text { expenditur } \\
\text { e policies }\end{array}$} & Fiscal investment & $\mathrm{O}$ & 0 & 00 & 00 \\
\hline & $\begin{array}{l}\text { Fiscal interest } \\
\text { discount }\end{array}$ & $\mathrm{O}$ & 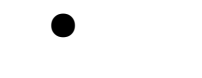 & 0 & \\
\hline & Fiscal subsidies & $\mathrm{O}$ & & & \\
\hline & Fiscal allocations & 0 & & & \\
\hline & Fiscal procurement & $\mathrm{O}$ & 0 & & 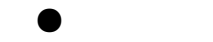 \\
\hline \multirow[t]{2}{*}{$\begin{array}{l}\text { Tax } \\
\text { policies }\end{array}$} & $\begin{array}{l}\text { Accelerated } \\
\text { depreciation and } \\
\text { investment tax credit }\end{array}$ & $\mathrm{O}$ & 0 & & \\
\hline & $\begin{array}{l}\text { Income tax reduction } \\
\text { and exemption }\end{array}$ & $\mathrm{O}$ & 0 & 0 & כ \\
\hline \multirow{2}{*}{$\begin{array}{l}\text { Financial } \\
\text { policies }\end{array}$} & Policy loans & $\mathrm{O}$ & 0 & 0 & 0 \\
\hline & Commercial loans & $\mathrm{O}$ & $\mathrm{O}$ & 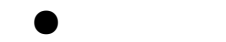 & O \\
\hline
\end{tabular}

Note: O Almost no effects; $\bullet$ Ordinary effects; $\bullet \bullet$ Notable effects

The structure of the paper is clarified as: Section 2 is about methodology; Section 3 introduces the context for the launch of the Golden-Sun Program; Section 4 describes changes in the policies about the Golden-Sun Program; Section 5 analyzes the success of the Golden-Sun Program; Section 6 assesses the failure of the Golden-Sun Program, and Section 7 is conclusions.

\section{METHODOLOGY}

Morthorst identified five key areas as the most important indicators for evaluating the process of wind power development: these are investment certainty, effectiveness, market competition, and administrative demands [40,41].

After studying the policy experience about renewable energy power in Denmark, Germany and the UK, Judith found that the top factor affecting the development of renewable energy in Europe is the long-term policy guarantee for investors, and then the actual implementation of the policies [42].

Morthorst' $\mathrm{s}$ conceptual framework was designed for renewable energy as a whole. In order to evaluate the Golden-Sun Program of China, we have to narrow down his conceptual framework to a more focused analytical model, which can be summarized by four indicators: policy system design, effectiveness, administration institution, and time frame/development period. Reasons are as follows:

Nowadays, market competition is not used due to the lack of market mechanisms in China; state regulations play a major role in the renewable-energy policies. Though it is generally agreed that "administrative demands" should give way to "market competition"in the long-term development context.

In the middle and long term, China's main tasks in developing the renewable energy industry are to establish complete and coordinated incentive policies for the renewable energy industry and gradually expand and stabilize the renewable energy market[43,44]. Whether the tasks can be successfully fulfilled depends on the coordination among renewable energy development on one hand, and economy development and environment protection on the other hand. The Chinese government defines the PV industry as a strategic emerging industry, which needs support from government policies at the initial stage because the investment costs are high and the market is at the growth stage. But whether the policy support is effective relies on the supporting system, the effective execution, and the coordinated and effective management system (See Fig.2.). 


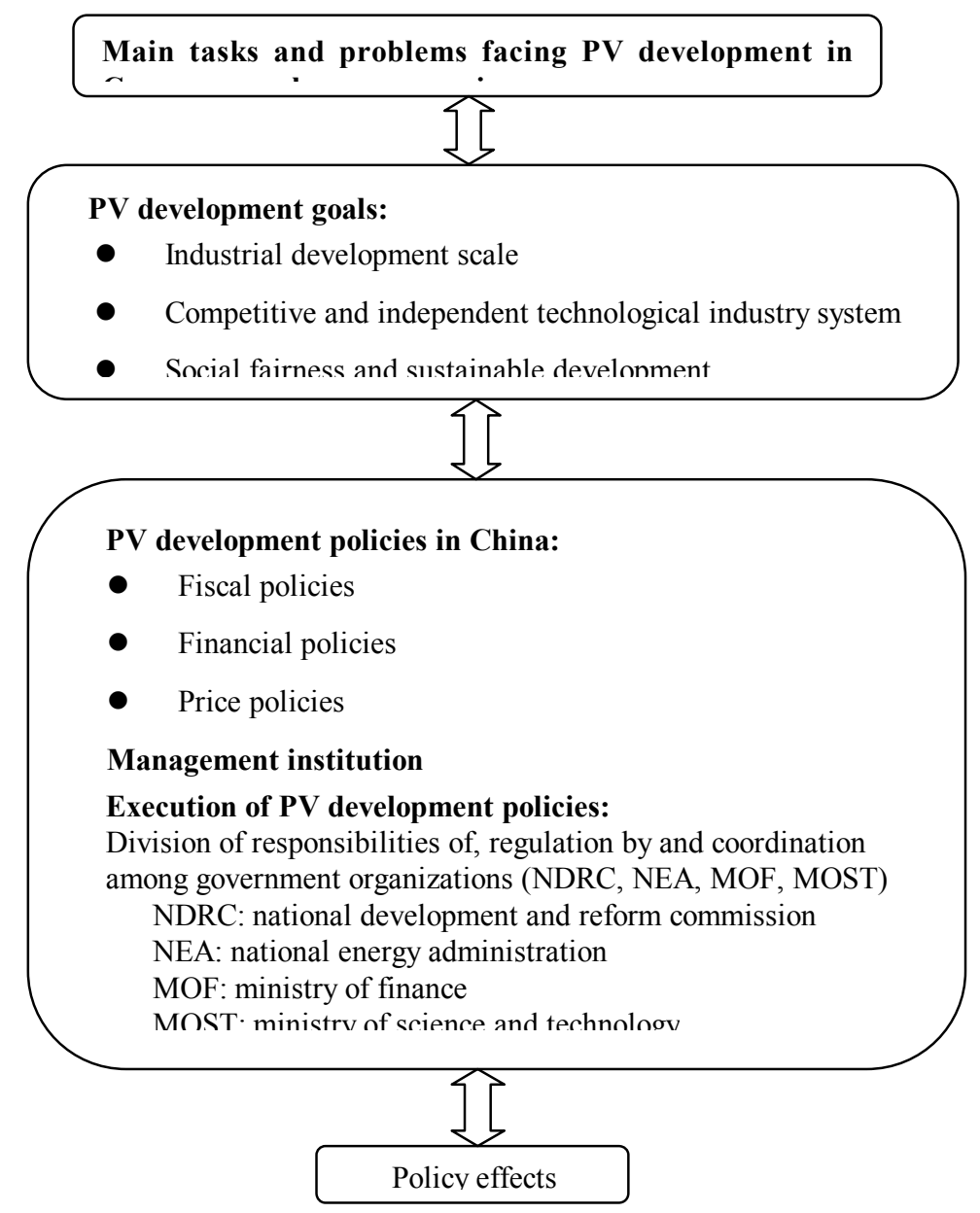

Fig.2. Linkage between China PV development policies, management institution and policy effects Source: Authors' own illustration.

To comprehensively assess development of the PV industry, we also need to review the roles of different incentives as policy instruments at various development stages of the PV power generation industry.

Effectiveness is the degree to which PV policies help promote renewable electricity. It is important to determine the optimal level of subsidies for the most suitable investment in PV. An overly high subsidy could be a potential threat to funding sources. The effectiveness level is very sensitive to the tariff set, production costs, administrative procedures and natural conditions. The experiences of Germany and Spain show that incentive policies can evolve from less-effective scenarios to more-effective ones after policy reform [40].

The third indicator that evaluates the Golden-Sun Program is administration institution.It is important to consider whether the purpose of policy-making is being fulfilled; the degree to which the implemented policy addresses each component of the most challenging issues. The obstacles to grid connection and lack of effective regulation leads to poor effectiveness of the Golden-Sun Program implementation.

The time frame/development period is another essential factor that should be considered during policy evaluation. The suitability of incentive policy should be tested over a certain period of time or a development period. Long-term examination could reveal weaknesses and allow the introduction of appropriate strategic solutions in a local context. During the evaluation process, one should bear in mind whether the policy adjustment has been in effect long enough to judge the results domestically[44,46].

For the sake of completely and objectively evaluating the success and failure of Golden-Sun Program of China, the four indicators: policy system design, effectiveness, administrative institution and time frame/development period are adopted in the research. Upon the analyze on realistic 
implementation effect of the program, we find there exist obvious experiences of success and lessons of failure (see Table 3).

Table 3. Evaluations of China's Golden-Sun Program

Source:Compiled by authors.

\begin{tabular}{|c|c|c|c|c|}
\hline & Policy system design & Effectiveness & $\begin{array}{l}\text { Administrative } \\
\text { institution }\end{array}$ & $\begin{array}{l}\text { Time frame/ } \\
\text { development } \\
\text { period }\end{array}$ \\
\hline \multirow[t]{2}{*}{$\begin{array}{l}\text { Success of the } \\
\text { Golden-Sun } \\
\text { Program }\end{array}$} & 1.Fiscal subsidies & $\begin{array}{l}\text { 1.Promoting } \\
\text { technological progress } \\
\text { and large-scale } \\
\text { development of domestic } \\
\text { PV power generation } \\
\text { industry }\end{array}$ & $\begin{array}{l}\text { 1. The State Grid changed } \\
\text { the traditional } \\
\text { management model }\end{array}$ & $\begin{array}{l}\text { 1.Large ground } \\
\text { PV power } \\
\text { stations are no } \\
\text { longer covered } \\
\text { by the } \\
\text { Golden-Sun } \\
\text { Program in } \\
2010 .\end{array}$ \\
\hline & $\begin{array}{l}\text { 2. Among the first batch of } \\
\text { projects supported by the } \\
\text { Golden-Sun Program, } \\
\text { user-side ones accounted } \\
\text { for } 47 \% \text {, large ground } \\
\text { power stations } 46 \% \text {, and } \\
\text { PV projects in the areas } \\
\text { without access to power } \\
7 \% \text {. } \\
\text { 3.Incentive expected } \\
\text { returns to investors }\end{array}$ & $\begin{array}{l}\text { 3. Bringing clean energy } \\
\text { to areas with no or } \\
\text { insufficient access to } \\
\text { power. }\end{array}$ & $\begin{array}{l}\text { 2. Management and } \\
\text { design of distributed PV } \\
\text { power generation are } \\
\text { improved significantly. }\end{array}$ & $\begin{array}{l}\text { 2. The subsidy } \\
\text { standards were } \\
\text { reduced in } \\
2011 .\end{array}$ \\
\hline \multirow[t]{4}{*}{$\begin{array}{l}\text { Failure of the } \\
\text { Golden-Sun } \\
\text { Program }\end{array}$} & $\begin{array}{l}\text { 1.Lack of systematic design } \\
\text { and effective coordination }\end{array}$ & $\begin{array}{l}\text { 1.Less than } 75 \% \text { of the } \\
\text { projects are put into } \\
\text { operation }\end{array}$ & $\begin{array}{l}\text { 1.Lack of effective } \\
\text { regulation }\end{array}$ & \\
\hline & $\begin{array}{l}\text { 2. The policy targets are not } \\
\text { clearly confined }\end{array}$ & $\begin{array}{l}\text { 2. The rate of grid } \\
\text { connection of the } \\
\text { Golden-Sun projects } \\
\text { already put into operation } \\
\text { was only } 40 \% \text {. }\end{array}$ & $\begin{array}{l}\text { 2.Local power supply } \\
\text { enterprises are reluctant } \\
\text { to let PV systems connect. }\end{array}$ & \\
\hline & $\begin{array}{l}\text { 3.Technological innovation } \\
\text { and R\&D are ignored }\end{array}$ & $\begin{array}{l}\text { 3.Poor quality and } \\
\text { efficiency of project } \\
\text { implementation. }\end{array}$ & & \\
\hline & $\begin{array}{l}\text { 4.Demand-side grid } \\
\text { connection and use of } \\
\text { self-generated power as } \\
\text { encouraged by policies are } \\
\text { hard to implement in } \\
\text { practice and fiscal subsidies } \\
\text { involve a long cycle to be } \\
\text { put in place. }\end{array}$ & & & \\
\hline
\end{tabular}

\section{CONTEXT FOR THE LAUNCH OF THE GOLDEN-SUN PROGRAM}

\section{A.Laws and policies regarding renewable energy}

In January 2006, the Renewable Energy Law of the People's Republic of China officially took effect; Afterwards, China successively launched a policy package including the Long and Medium-term Plan for the Development of Renewable Energy and the 11th Five-year Plan for the Development of Renewable Energy [47](see Table 4), which not only specified the general goals for China's renewable energy development, but also set long and medium-range goals for some industries. To achieve these 
goals, the Chinese government also specified incentives for renewable energy power generation in the Renewable Energy Law, Trial Measures for Management of Allocation of Renewable Energy Power Tariff and Expenses and Interim Measure for Allocation of Additional Revenue from Renewable Energy Power Tariff. There are three main principles:

Power grid enterprises must purchase the feed-in power generated from renewable energy in full amount;

- Power grid enterprises purchase the power generated from renewable energy based on the feed-in power tariff that combines reasonable costs and reasonable profits;

- The difference between renewable energy power tariff and conventional tariff is allocated in power grid across the country.

In early 2009, China's policies regarding renewable energy power connection have basically taken shape. As for actual implementation, the tariffs and tariff mechanisms have been defined for the power generated from wind and biomass, but no tariffs or tariff mechanisms has been specified for PV power [45]. As the FIT policies have never been clarified, China's PV power generation market has developed slowly. Before 2008, PV power was mainly used in off-grid projects, such as rural electrification, communications and industries (See Table 5).

Table 4. China's laws and policies regarding renewable energy (2005-2011)

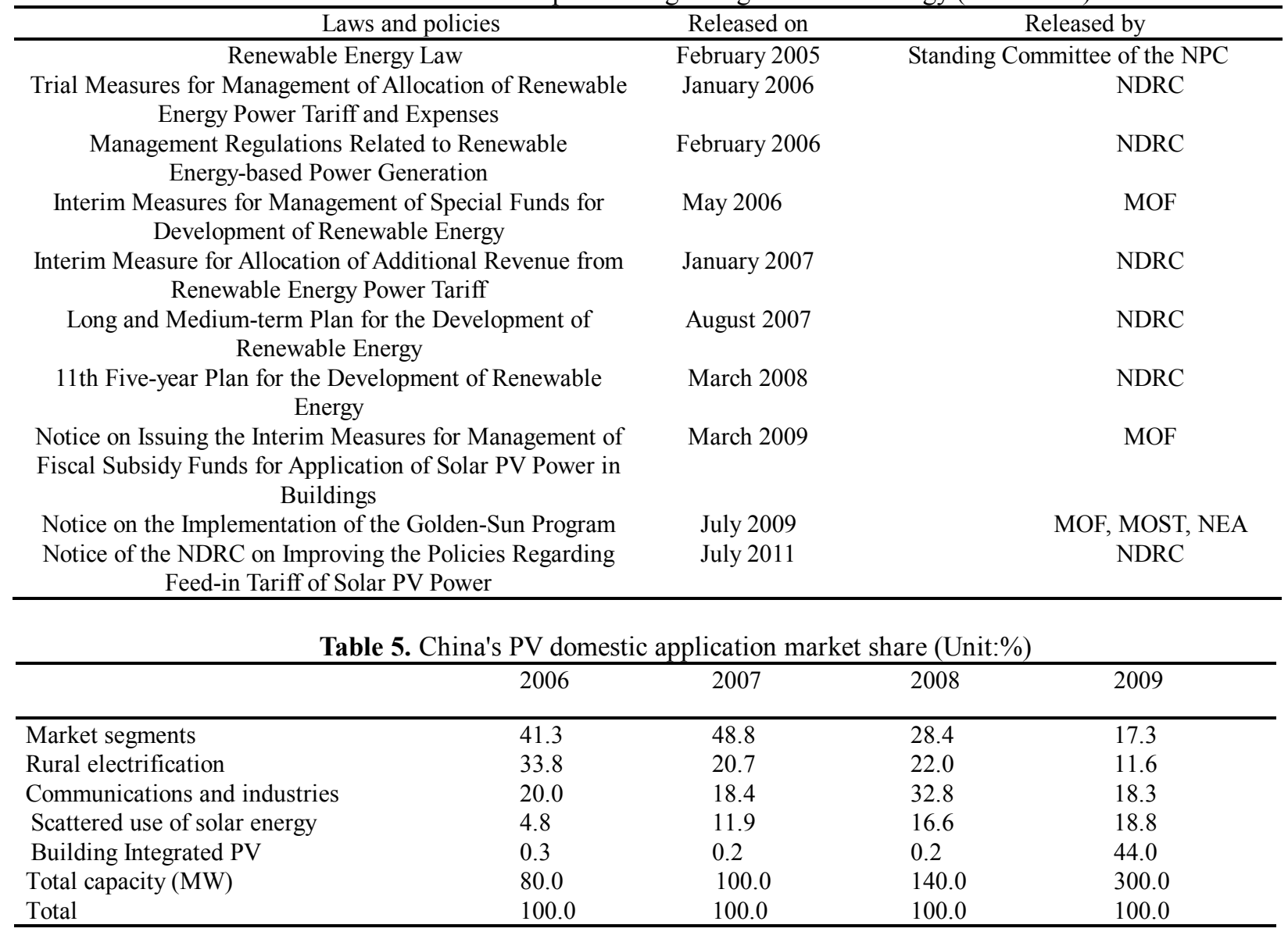

\section{B.Analysis of China's incentive policies for $P V$ power generation}

Since 2008, the Chinese government has introduced an incentive package for PV power generation to kick off domestic PV market. For eastern provinces with robust economic strength, the government offers additional subsidies for PV power generation projects with self-raised funds and implements local policies on fixed FIT to promote the development of local PV industry. Jiangsu Province is the most representative one of all. 
In summary, there are two major types of incentive policies for PV power generation in China, i.e. subsidy policies for initial investment and policies regarding fixed FIT[48] (See Table 6). The subsidy policies for initial investment are mainly applicable to small and medium-sized PV power generation systems, such as solar building integrated PV demonstration projects (Solar Rooftop Program for short); as for large PV power stations, the approval policy is adopted in which one FIT is for one project, or tariffs are defined differentially.

Table 6. China's main PV subsidy policies

\begin{tabular}{|c|c|}
\hline Project types & PV subsidy policies \\
\hline $\begin{array}{l}\text { Solar Rooftop } \\
\text { Program }\end{array}$ & $\begin{array}{l}\text { Projects with an installed capacity of } 50 \mathrm{~kW} \text { or above; Subsidy standard: } 20 \text { yuan/W in 2009, and } 17 \text { yuan/W } \\
\text { in } 2010 . \\
\text { Fund source: Special funds for renewable energy development }\end{array}$ \\
\hline $\begin{array}{l}\text { PV power FIT } \\
\text { projects }\end{array}$ & $\begin{array}{l}\text { Among the 100-plus feed-in PV power generation projects built nationwide in } 2007 \text { and 2008, the NDRC } \\
\text { only approved four PV power station projects in two batches, including two in Shanghai, one in Inner } \\
\text { Mongolia and one in Ningxia, with the FIT as } 4 \text { yuan/kWh. } \\
\text { Fund source: Renewable energy power tariff surcharges levied nationwide ( } 2 \text { thousandth of a yuan } / \mathrm{kWh} \text { ) }\end{array}$ \\
\hline $\begin{array}{l}\text { Franchise PV } \\
\text { bidding } \\
\text { projects }\end{array}$ & $\begin{array}{l}\text { In } 2009 \text {, the NEA organized franchise bidding for the } 10 \mathrm{MW} \text { PV power station in Dunhuang, Gansu } \\
\text { Province, with the FIT as } 1.0928 \text { yuan/kWh and the franchise operation period as } 25 \text { years; In } 2010 \text {, the } \\
\text { NEA launched the second round of franchise bidding, resulting in } 0.7288-0.9791 \text { yuan } / \mathrm{kWh} \text { of power tariffs } \\
\text { in thirteen } 20-30 \mathrm{MW} \text { projects in western China based on the principle of bid winning at the lowest price. }\end{array}$ \\
\hline $\begin{array}{l}\text { FIT project in } \\
\text { Jiangsu } \\
\text { Province }\end{array}$ & $\begin{array}{l}\text { Target tariff of ground feed-in power stations: } 2.15 \text { yuan } / \mathrm{kWh} \text { in } 2009 \text {, and } 1.7 \text { yuan } / \mathrm{kWh} \text { in } 2010 \\
\text { Fund source: Special funds for PV power generation set up by imposing additional tariffs }\end{array}$ \\
\hline
\end{tabular}

The following problems can be discovered from the review of the main PV subsidy policies implemented in China:

\section{Projects under the Solar Rooftop Program are relatively small}

The Solar Rooftop Program is implemented on the basis of the Implementation Opinions on Accelerating Application of Building Integrated Solar PV released by the MOF and the Ministry of Housing and Urban-Rural Development. But the projects under the Solar Rooftop Program are relatively small in scale. In 2009, 111 projects with a total capacity of around $91 \mathrm{MW}$ were approved as eligible for the Solar Rooftop Program, receiving 1.3 billion yuan of subsidies across China [49].

\section{The franchise PV bidding prices are relatively low}

Considering that franchise PV bidding is a major means for a country to learn about prices, the Chinese government intends to employ this means to promote the development of China's PV industry. The implementation of franchise bidding projects leads to a substantial decline in feed-in PV power tariff from 4 yuan $/ \mathrm{kWh}$ in 2008 to $1.09 \mathrm{yuan} / \mathrm{kWh}$ in the first franchise bidding project in 2009 . But among the franchise bidding projects, the principle of bid winning at the lowest price results in significant reduction of project returns by bidding enterprises (the internal rates of returns of some projects are even below 5\%), which obviously goes against the sustainable development of the PV market.

\section{The FIT policies are not in place}

The delay in defining FIT leads to difficulties in identifying the period of investment returns by enterprises. With unclear returns, investors will find it hard to take interest in PV power generation projects, which objectively restricts development of feed-in PV power generation. Feed-in PV power generation must be fostered with a mixture of price means and market mechanisms, and China is in an urgent need to launch fixed feed-in tariff to push forward market development and offer market guarantee for the large-scale development of the PV industry.

\section{C.Influence of the financial crisis on China's PV industry}

China's PV manufacturing industry has been expanded as pushed by the huge demand in European market. Pinched by the US financial crisis and European debt crisis, China's PV industry has seen a shrinking international market since 2009, with exports hampered and some PV enterprises shut down. 
The financial crisis gives rise to signs of trade protection in some developed countries, which increases risks and uncertainties to China's PV power generation industry. The strong negative influence of the financial crisis on China's PV product manufacturing attracts great attention from the Central Government, which had set the strategic goal of making non-fossil energy representing $15 \%$ of the total by 2020. In 2009, the Central Government devised the strategic guidelines of "maintaining growth, adjusting structures and expanding domestic demand". Promoting the large-scale development of China's PV market is both required by energy conservation, emission reduction and improvement in China's energy structure, and an effective measure to reduce risks in domestic PV market as well.

Given the economic and financial situations both at home and abroad, the Chinese government determined to increase incentives for the PV industry, in the hope of seizing the strategic opportunities for the development of PV power generation, kicking off domestic PV power generation market and expanding the presence of China's PV power generation industry in the world. The Golden-Sun Program was launched against the said backdrop.

\section{CHANGES IN THE POLICIES ABOUT THE GOLDEN-SUN PROGRAM}

\section{A.Process for implementing the Golden-Sun Program}

On July 16, 2009, the MOF jointly with MOST and NEA released the Notice on the Implementation of the Golden-Sun Program, which pointed out that to promote the technological progress and large-scale development of PV power generation and foster strategic emerging industries, the Central Government shall allocate some special funds for renewable energy to support demonstration application of PV power generation technologies in various fields and industrialization of key technologies (the Golden-Sun Program in short) [47]. The Notice specified the main steps for implementing the Golden-Sun Program, as described in follows:

First, provincial-level departments of finance, science and technology and energy specify the areas, contents and schedules for the construction of demonstration projects in accordance with the implementation plans for the Golden-Sun Program, and jointly report them to the MOF, MOST and NEA for putting on record.

Second, as for the projects included in the implementation plan, proposals and key equipment bidding shall first be completed. After local power grid enterprises give opinions that they agree connecting the power into grid, application for fiscal subsides can be filed. In the principle of territory, the application shall be submitted to the competent provincial-level departments of finance, science and technology and energy, who shall further submit the application to the MOF, MOST and NEA at the end of each February and August after organizing review of the application reports.

Finally, the MOF, MOST and NEA review the technical plans as well as materials about construction conditions and fund raising related to the projects. Afterwards, the MOF defines the subsidy amounts according to project investment and subsidy standards, arranges budgets based on $70 \%$ of the amounts, and settles the remaining subsidy funds according to actual project investment (See Fig.3.). 


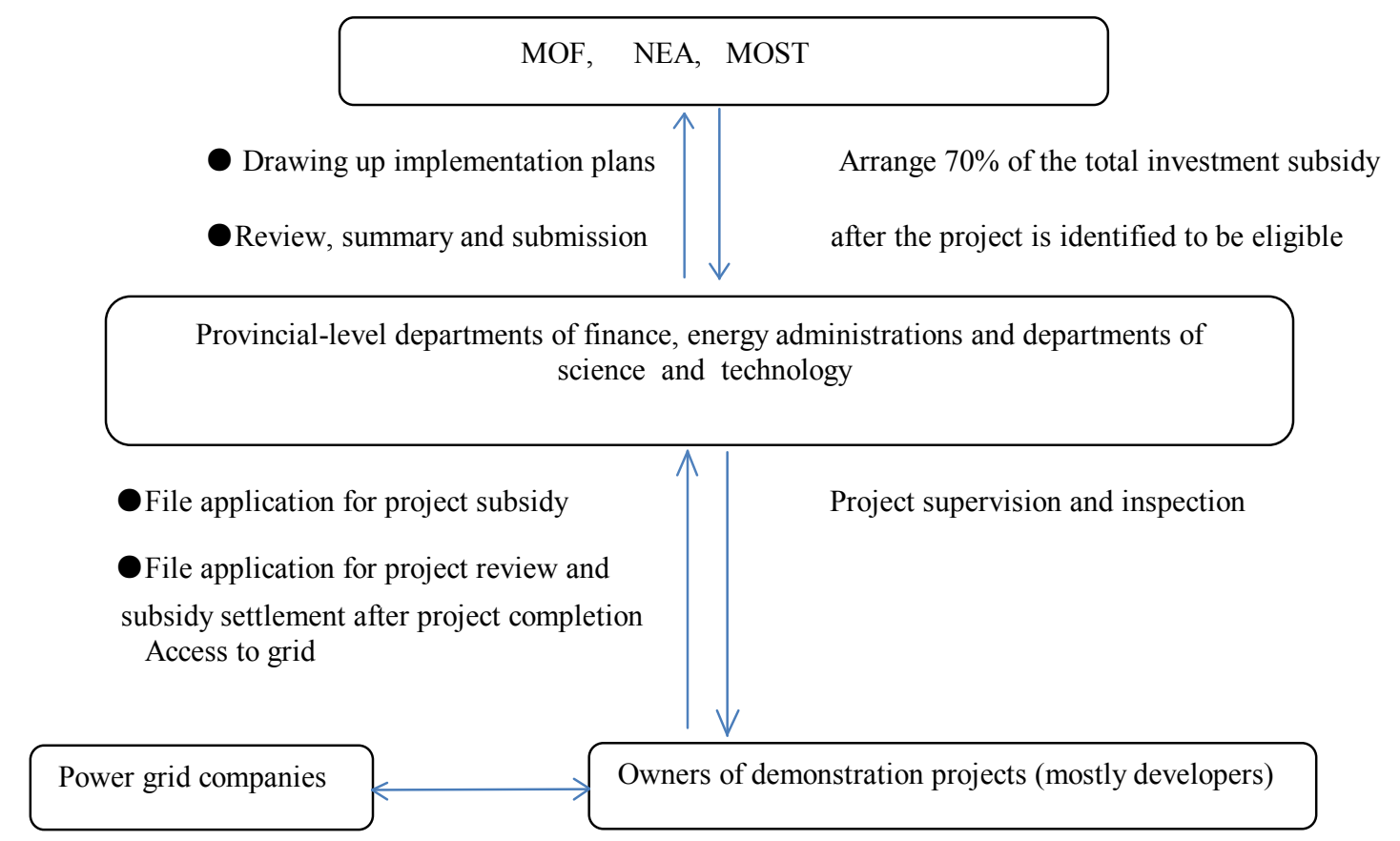

Fig.3. Implementation process of the Golden Sun program

Source: Authors' own illustration

\section{B.Areas covered by the Golden-Sun Program and implementation measures}

The Golden-Sun Program is an emergency policy launched by China to deal with the international financial crisis and promote the technological progress and large-scale development of domestic PV power generation industry. With changes in the PV market both at home and abroad, the policy measures have been adjusted slightly (see Table 7). 
Table 7. Main conditions, supported areas and measures for implementing the Golden Sun Program (2009-2012)

\begin{tabular}{|c|c|}
\hline $\begin{array}{l}\text { Document name, } \\
\text { approval No. and } \\
\text { date of release }\end{array}$ & $\begin{array}{l}\text { Conditions and requirements for projec } \\
\text { implementation }\end{array}$ \\
\hline $\begin{array}{l}\text { Notice on the } \\
\text { Implementation of } \\
\text { the Golden Sun } \\
\text { Program, No. } 397 \\
{[2000] \text { of the }} \\
\text { Ministry of } \\
\text { Finance, July } 2009\end{array}$ & $\begin{array}{l}\text { The installed capacity of a single } \\
\text { project is no less than } 300 \mathrm{~kW} \text {; } \\
\text { The developer has a total asset of no } \\
\text { less than } 100 \text { million yuan, and the } \\
\text { capital fund is no less than } 30 \% \text { of the } \\
\text { total investment; } \\
\text { Key equipment for demonstration } \\
\text { projects, including PV modules, } \\
\text { inverters and storage cells, are chosen } \\
\text { through bidding. }\end{array}$ \\
\hline
\end{tabular}

Strengthening the

Management of

Construction of

Golden Sun

Demonstration

Projects and

Demonstration

Projects of

Application of

Building

Integrated Solar

PV, No. 662

[2010] of the

Ministry of

Finance,

September 2010

Notice on

Effectively

Conducting the

Golden Sun

Demonstration

Work in 2011, No.

380 [2011] of the

Ministry of

Finance, June

2011

\section{Notice on \\ Effectively \\ Conducting the \\ Golden Sun \\ Demonstration \\ Work in 2012, No. \\ 21 [2012] of the \\ Ministry of \\ Finance, January 2012}

1.The installed capacity of the user-side PV power generation projects under concentrated and continuous construction is no less than $20 \mathrm{MW}$; 2.Key equipment is identified through unified bidding.

1.The installed capacity of the user-side $\mathrm{PV}$ power generation projects under concentrated and continuous construction is no less than $20 \mathrm{MW}$; 2.The installed capacity of user-side PV power generation projects is no less than $300 \mathrm{~kW}$;

3. No unified biddings are organized for key equipment, and equipment complies with standards.

1.The total installed capacity of demonstration projects under concentrated application is no less than $10 \mathrm{MW}$; the installed capacity of user-side power generation projects under scattered construction is no less than $2 \mathrm{MW}$;

2.Key equipment is purchased independently.
Supported areas

1.Demonstration projects of PV power generation for user-side grid connection by large industrial and mineral enterprises, commercial enterprises and public welfare institutions;

2.PV and wind and solar projects in remote areas and areas without access to power;

3.Large-scale grid connection PV power generation projects in the areas rich in solar energy resources;

4.Demonstration projects for industrialization of key technologies in PV power generation.

1.Support priorities shall be given to user-side PV power generation projects constructed by large industrial and mineral enterprises, commercial enterprises and public welfare institutions by using the established buildings and other conditions; 2.Independent $\mathrm{PV}$ power generation projects in remote areas and areas without access to power;

3.User-side PV power generation projects under concentrated and continuous construction in economic and high-tech development zones.

1.User-side PV power generation projects under concentrated and continuous construction in economic and high-tech development zones; 2.Demonstration projects of PV power generation for grid connection at the user side of large industrial and commercial enterprises and public welfare institutions;

3.Independent PV power generation projects in remote areas and areas without access to power;

Supplement to provisions in 2009: Other expenses for the construction of demonstration projects are subsidized on the basis of fixed amounts with a standard of 4 yuan/W.
Implementation

measures

\section{PV power}

generation projects for grid connection are subsidized on the basis of $50 \%$ of the total

investment, and the independent

PV power

generation systems in remote areas or areas without access to power are subsidized on the basis of $70 \%$ of the total investment.

Supplement to provisions in 2009: Other expenses for the construction of demonstration projects are subsidized on the basis of fixed amounts with a standard of 4 yuan/W.

Previous investment subsidy policies are cancelled, and the subsidy standard for demonstration projects is 8-9 yuan/W.

The standard project subsidy is 7 yuan/W.

On July 16, 2009, the MOF, MOST and NEA jointly released the Notice on the Implementation of the Golden-Sun Program, deciding to accelerate the large-scale industrialization of domestic PV power generation by using fiscal subsidies, scientific and technological support and market incentives. The said three ministries and commissions planned to financially support PV power generation demonstration projects with the installed capacity not less than $500 \mathrm{MW}$ in the next two to three years.

In 2009, 140 projects were approved as eligible for Phase I demonstration projects, to be completed in three years. 
In 2010, large feed-in PV power stations are no longer covered by the Golden-Sun Program, and the rest of the supported areas were basically the same as those in 2009.

In 2011, the Golden-Sun Program highlighted support to the user-side PV power generation projects in economic and technological development zones and industrial parks. The subsidy standards were somewhat adjusted, i.e. key equipment bidding is no longer organized and equipment's compliance with standards is the key. Subsidies for initial investment are still adopted.

In the first half of 2012, the subsidy standards for Golden-Sun projects were adjusted.

In March 2013, the MOF decided to cease the review of new project applications related to the Golden-Sun Program; in May 2013, the MOF settled accounts related to the Golden-Sun projects.

Effectiveness of implementation of the Golden-Sun Program. From 2009 to 2012, a total of 655 projects in five phases were approved under the Golden-Sun Program, involving a total capacity of 5,930 MW (see Table 8) and fiscal subsidies of 28 billion yuan on a cumulative basis [50] (See Fig.4.).

Table 8. Approved projects under the Golden-Sun Program

\begin{tabular}{ccc}
\hline Phase & Project number & Project capacity (MW) \\
\hline Phase II in 2010 & 46 & 271.7 \\
Phase III in 2011 & 129 & 792.1 \\
Phase IV in June 2012 & 155 & 1732.2 \\
Phase V in November 2012 & 185 & 2830.0 \\
Total & 655 & 5930.0 \\
\hline
\end{tabular}

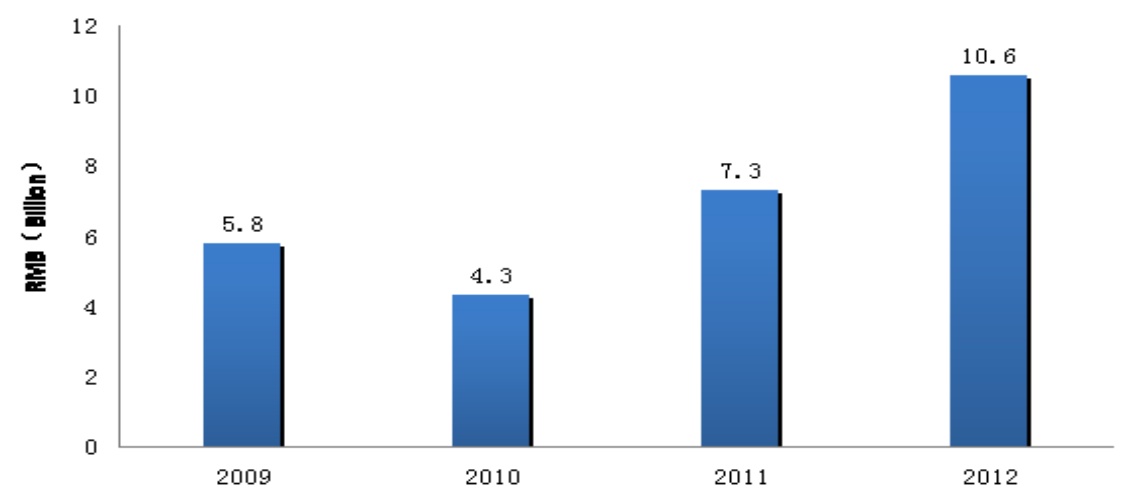

Fig.4. Subsidies to the Golden-Sun Program (2009-2012)

The Golden-Sun Program has pushed forward the rapid development of China's PV market as a whole, but newly increased PV capacities vary greatly with provinces (municipalities and autonomous regions) (see Fig.5.). 


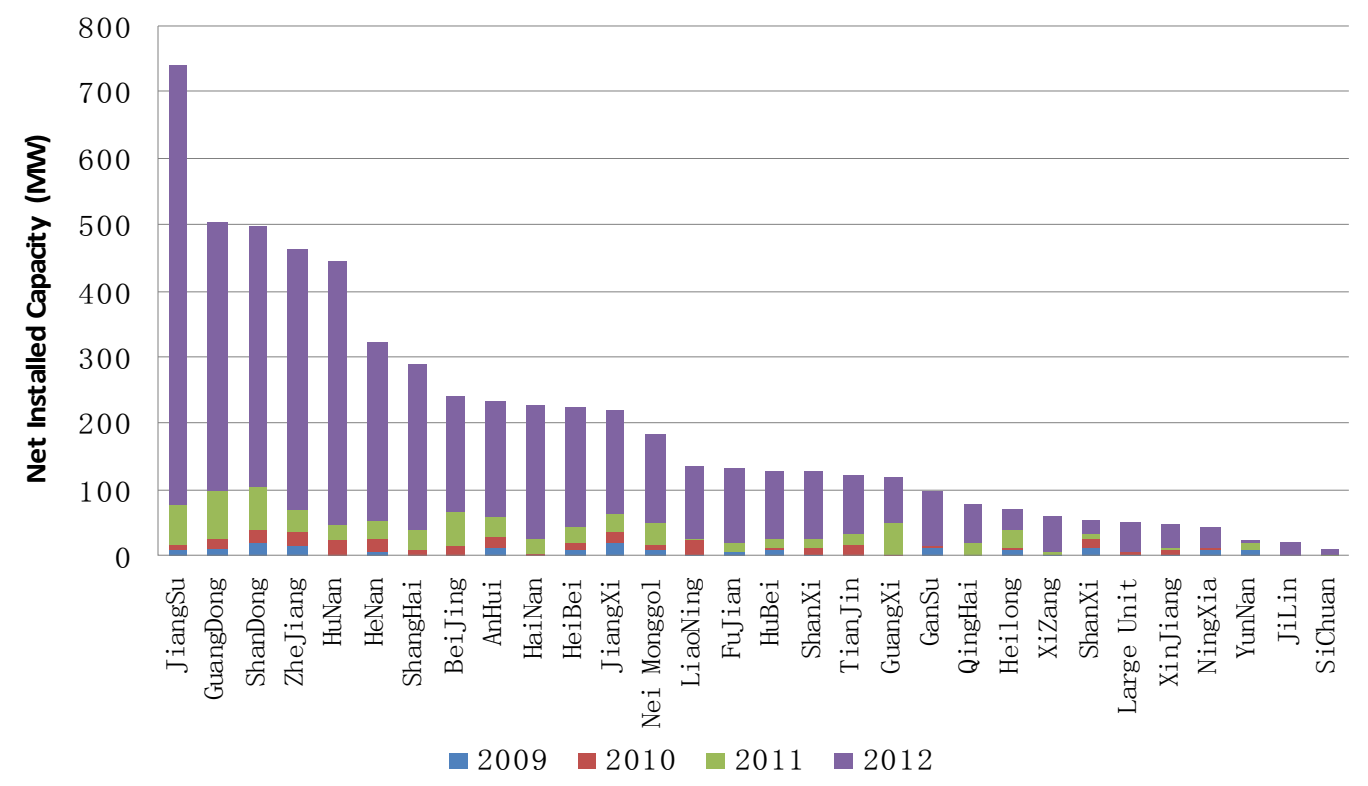

Fig.5. Increased capacities under the Golden-Sun Program in provinces (municipalities and autonomous regions)

\section{SUCCESS OF THE GOLDEN-SUN PROGRAM}

\section{A. At the demonstration growth stage of the PV power generation industry, fiscal subsidies play a} notable role in promoting growth of China's PV market

Subsidies under the Golden-Sun Program refer to giving upfront funds that represent $50 \%$ of the total project investment to project investors in cash before project construction. In general, $70 \%$ of the subsidy funds will be paid prior to project construction, and the remaining $30 \%$ will be paid after project completion.

Before 2009, most commercial banks were reluctant to grant loans to PV power generation projects with unclear prospects, and private investors also did not prefer PV power generation projects with low rates of returns. Therefore, the PV industry had long been waiting for government policies about subsidizing PV users, which can truly enable effective connection between PV industrial investment and market consumption. But this obviously is a long process. The launch of the Golden-Sun Program greatly shortens such a process. Industrial investors and even financial investors immediately take interest in investment in PV power stations.

Before 2009, China's PV market developed slowly, with more than 95\% of PV modules exported abroad. After 2009, domestic PV market grew by more than $100 \%$ annually, with the export share declining from more than $95 \%$ in the years before to $82.5 \%$ in 212 , as shown in Table 9 .

\begin{tabular}{lccccccc}
\multicolumn{8}{c}{ Table 9. Shares of PV module export in China (2006-2012) } \\
\hline Year & 2006 & 2007 & 2008 & 2009 & 2010 & 2011 & 2012 \\
& & & & & & & \\
\hline Export share (\%) & 97.5 & 98.2 & 98.5 & 96.0 & 95.4 & 87.9 & 82.5
\end{tabular}

As of the end of 2012, the projects covered by the Golden-Sun Program involved a total installed capacity of 5,930 MW (see Table 10), wherein over 95\% of such projects were distributed PV power generation projects. Therefore, China's distributed PV power generation made great headway, and the share of distributed PV systems in China's PV system market increased from $32.0 \%$ in 2011 to $36.4 \%$ in 2012. In particular, the Golden-Sun Program contributed to $80 \%$ of the development [49]. 
Table 10. Capacity of projects under the Golden-Sun Program (2009-2012)

\begin{tabular}{lccccc}
\hline Year & 2009 & 2010 & 2011 & 2012 & Total \\
\hline Project capacity (MW) & 216 & 275 & 692 & 4,747 & 5,930 \\
\hline
\end{tabular}

In a word, the Golden-Sun Program quickly kicks off and accelerates the development of China's PV market.

\section{B.The Golden-Sun Program significantly improves the efficiency of constructing PV power}

\section{generation facilities at home}

Due to implementation of the Golden-Sun Program and positive signals in the international market, China's PV market size and production scale have been expanded, the PV industry has been improved step by step, output of polysilicon materials has increased substantially and the cost declined, and prices of PV modules and PV systems have declined rapidly. According to a survey of PV module producers at the end of 2012, China's PV module manufacturing cost was about US\$ 0.62-0.65[49]. Compared with 2007, prices of PV modules declined by $87.5 \%$, and system prices decreased by $83.3 \%$ (see Fig.6.).

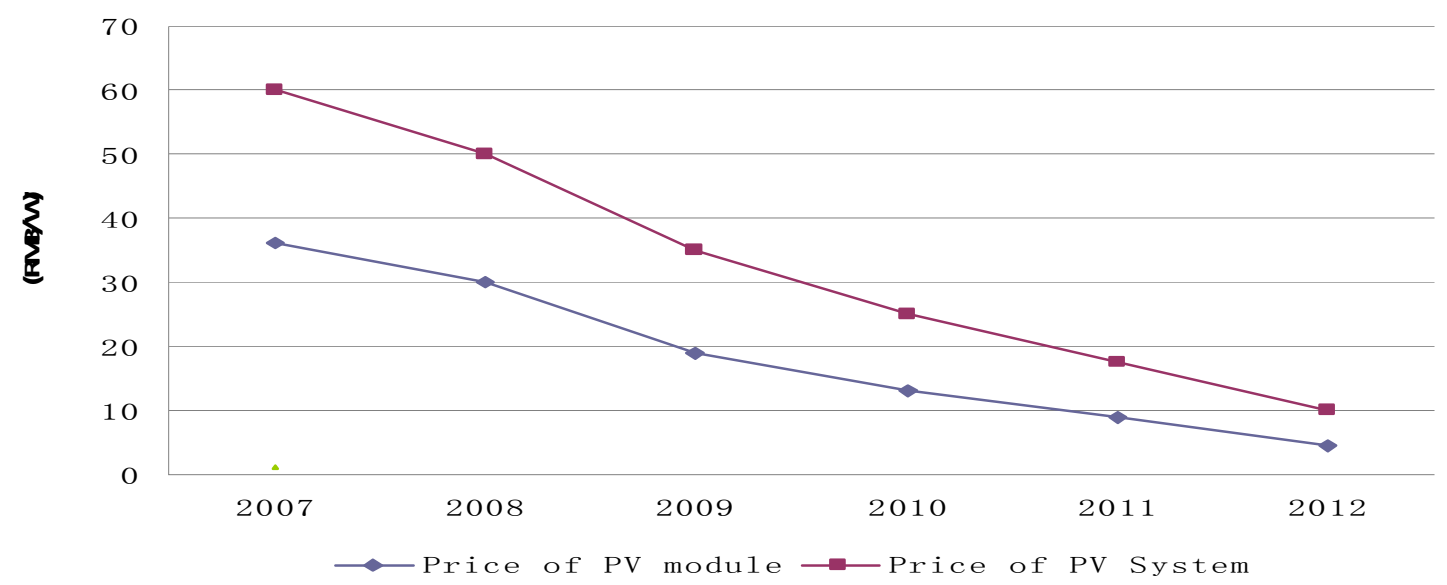

Fig.6. Changes in the prices of China's PV modules and PV systems

\section{C.The Golden-Sun Program provides clean energy to residents in rural areas with no or insufficient access to power}

The sparsely-populated and under-developed areas in western China are main beneficiaries of the Golden-Sun Program, which provides electricity to residents in remote mountainous areas in western China and brings clean energy to areas with no or insufficient access to power. Data shows that after three years of implementation of the Golden-Sun Program, local governments in Qinghai Province have applied for 46 projects, 15 of which were approved by the State and involved a total installed capacity of 33.4 MW and a subsidy of 552 million yuan from the Central Government. Benefiting from these projects, grassland herders gain better access to power in both living and production and share the fruits of technological civilization[53].

\section{D.Management and design of distributed PV power generation are improved significantly}

Implementation of the Golden-Sun Program prompts a series of relevant standards and measures (see Table 11). 
Table 11. Standards and codes related to distributed PV power generation

\begin{tabular}{lc}
\hline \multicolumn{1}{c}{ Standards and codes } & No. \\
\hline Technical Code for Solar PV System of Civil Buildings & JGJ 203-2010 \\
Code for Operation and Maintenance of Building Mounted Photovoltaic & JGJ/T 264-2012 \\
System & 20111728-T-424 \\
Code for Acceptance of Building Integrated PV Power Generation Systems & \\
Technical Requirements for Connecting Photovoltaic Power System to & GB/T 29319-2012 \\
Distribution Network & CGC/GF003.1-2009 \\
Basic Acceptance Requirements for Grid-connected PV Systems &
\end{tabular}

To support implementation of the Golden-Sun Program, the State Grid changed the traditional management model in the power industry and released the Opinions on Effectively Conducting Grid Connection of Distributed PV Power in March 2013, which brings hope to China in breaking through the institutional obstacles to grid connection of distributed PV power.

Thanks to implementation of the Golden-Sun Program, China's design of distributed PV systems has improved significantly in terms of resource assessment and power generation forecast, building integrated PV design and solutions about orientations, shading and heat radiation, optimization and coordination of the tile angle of PV array, generating capacity, land occupied and wind resistance, design of PV systems and buildings, construction of building PV, design of grid connection systems, monitoring of distributed PV power generation as well as operation and maintenance of building PV systems. Meanwhile, China has fostered a number of PV system design and engineering construction talents as well as a number of highly professional and experienced enterprises.

\section{FAILURE OF THE GOLDEN-SUN PROGRAM}

\section{A.Lack of systematic design and effective coordination in policies}

Stable and clear government commitment is the most key factor to policy success. The commitment includes price levels, effective terms, scope of participants as well as other supporting policies and implementation. The periods of protecting and supporting the PV power generation industry must be long enough to ensure its strong competitiveness compared with that of traditional energy. However, changeable policy orientations and poor implementation of supporting policies hurt investors. For example, Phase I Golden-Sun projects initiated in 2009 were planned to be completed in two to three years, but only fewer than half of the projects have been commenced. This is partly attributed to developers' intentional delay to reduce cost, but most importantly is the failure to implement supporting policies. Specifically speaking, the power generated cannot be connected to grid; user-side grid connection and use of self-generated power as encouraged by policies are hard to implement in practice and fiscal subsidies involve a long cycle to be put in place.

The Golden-Sun Program is a policy means launched as an emergency response to the unbalanced PV supply and demand and outstanding problems in the international market, but it lacks coordination and continuity in implementation. Therefore, policy changes become usual [54].

\section{B.Institutional deficiencies in policy design}

The Golden-Sun Program has two major institutional deficiencies: unclear and biased policy guidelines and unscientific subsidies. Details are as follows:

The policy targets are not clearly confined to the users who generate PV power for self-use. In 2009, among the first batch of projects supported by the Golden-Sun Program, user-side ones accounted for $47 \%$, large ground power stations $46 \%$, and PV projects in the areas without access to power $7 \%$.

As for the installed capacity of a single power station, the lower limit rather than the upper limit is defined, and the lower limit has been raised year by year . 
- The subsidy standards do not take into account the rapid decline in cost resulted from market competition, and are close to the cost of PV modules (see Table 12). The excessively high subsidy standards make owners of the Golden-Sun projects tend to purchase low-price equipment to reduce cost, which may do harm to the engineering quality. In 2010, the MOF announced the cancellation of 39 projects intending to make up the number, which involved a total installed capacity of 54 MW [50].

\begin{tabular}{|c|c|c|c|c|}
\hline & 2009 & 2010 & 2011 & 2012 \\
\hline PV module costs & 19 & 13 & 9 & 4.5 \\
\hline PV subsidies & 20 & 12 & 8- 9 & 5.5 \\
\hline
\end{tabular}

Technological innovation and R\&D are ignored. Although technological R\&D is covered by the Golden-Sun Program and is offered certain incentives, it plays a very minor role when compared to the investment in PV power generation demonstration projects. As a result, China's PV industry has made certain headway in technologies, but the core technologies still lag far behind those of developed countries.

\section{C.Obstacles to connecting user-side PV systems to the grid}

Although the State Grid released the Opinions on Effectively Conducting Grid Connection of Distributed PV Power in March 2013, which provided policy foundation for distributed PV user-side grid connection, the Golden-Sun Program was hampered by the PV system user-side grid connection during the whole implementation process (2009-2012), and the rate of grid connection of the Golden-Sun projects already put into operation was only $40 \%$. This greatly reduces the effects of the Golden-Sun Program [55].

The common problem existing during implementation of the Golden-Sun Program is that local power supply enterprises are reluctant to let PV systems connect to the grid at the user side, but hope to manage PV power generation projects through public power stations. This leads to construction of booster stations under the Golden-Sun Program for concentrated grid connection from the transmission networks. But this conflicts with the user-side grid connection and use of self-generated power required by the Golden-Sun Program, i.e. the principle of operating the PV systems by offsetting quantities of power. That way, the values of PV power decline from the user-side power tariff (the average tariff of power for industrial and commercial use in eastern China is about $0.925 \mathrm{yuan} / \mathrm{kWh}$ ) to the feed-in benchmark tariff of power generated by local desulphurized coal-fired units (only about $0.35 \mathrm{yuan} / \mathrm{kWh}$ ), resulting in the total loss of project profitability. Moreover, compared with the power stations that use the power they generate, public power stations involve much higher construction cost, more complex approval procedures and longer period of time. So, the Golden-Sun Program has encountered the difficulty in user-side grid connection at the very beginning.

The obstacles to grid connection under the Golden-Sun Program are mainly attributed to the institutions. First, the Golden-Sun Program policies are mainly driven by the MOF, but the MOF fails to coordinate with power grid enterprises when devising the policies. This results in numerous difficulties in grid connection at later stages; and second, as the Golden-Sun Program encourages user-side grid connection and use of self-generated power and adopts the way of offsetting power quantities, owners purchase significantly fewer quantities of power from power grid enterprises, thereby affecting their economic benefits. Due to the lack of reasonable profits and incentives, power grid enterprises are somewhat against grid connection of the Golden-Sun projects. 


\section{D.Lack of effective regulation leads to poor quality and effectiveness of project implementation}

As the regulator of the power market, the State Electricity Regulatory Commission is responsible for regulation of power enterprises, power scheduling trading and fair opening of power grid by enterprises. However, regulation over PV power generation projects lacks supporting laws and regulations. The Notice on the Implementation of the Golden-Sun Program pointed out that local departments of finance, science and technology and energy are responsible for supervising and inspecting implementation of the Golden-Sun projects. But there are difficulties in executing the provision, as there are no detailed definition about who will dominate and coordinate the supervision and inspection and who will take the main responsibilities, resulting in the absence of regulation after the Golden-Sun projects are approved and implemented.

Even if local departments of finance, science and technology and energy are willing to supervise Golden-Sun projects, the huge supervision costs would deter them from coming forward. Projects need to be applied, reviewed and approved before implementation and be accepted after completion, and supervision after project acceptance is even more complex and difficult. So, a few number of Golden-Sun projects can be supervised in theory, but it is really hard to supervise more than 650 projects at the same time.

As the subsidies for the Golden-Sun projects are allocated beforehand based on application and follow-up project regulation fails to be implemented, it is hard to control the quality of equipment and engineering construction, the scale of actual grid connection and the quality of power stations. It is also difficult to bring the qualities of power generated as the most key part to the applied level, and less than $75 \%$ of the projects are put into operation $[3,52]$. Huge subsidies offered have not produced ideal results in fueling the demand for China's PV products.

\section{CONCLUSIONS}

The Golden-Sun Program is an emergency policy launched by China to deal with international financial crisis and promote the technological progress and large-scale development of domestic PV power generation industry. The policy measures and supported areas have been adjusted with the changes in the PV market both at home and abroad.

A clearly defined FIT system has far-reaching significance in the shaping of the PV power generation market. Explicit FIT means clear expected returns to investors. In early 2009, China's FIT for renewable energy power had basically taken shape. But the policies regarding PV power FIT have not been made clear, which hinders the development of China's PV power generation market. The Golden-Sun Program was launched as the only choice against the backdrop in which no fixed feed-in benchmark tariffs are available, and an effective means to quickly kick off the market as well.

Under the Golden-Sun Program, subsidies for investment are offered at the initial stage, and huge fiscal funds are used, which has institutional deficiencies. First, the subsidy standards are hard to define with market and cost changes in a reasonable manner; second, the subsidy standards are not assessed on the basis of the quantities of power generated, but on the installed capacity, which plays a limited role in promoting PV power generation; and third, the regulation cost involved in the Golden-Sun Program is very high.

In the Golden-Sun Program, lump-sum subsidies are consumed, but project supervision has not been implemented after governments allocate subsidy funds to enterprises. It is a lesson to be learned in future scaling-up and management of distributed PV power generation projects.

\section{References}

[1] Yu-wen Zhao, Problems in China's PV industry and countermeasures, Renewable Energy Resources (2), 5-8(2004).

[2] Yu-wen Zhao, Current development of China's PV industry and prospects, Solar Energy (18), 32-38(2012). 
[3] Si-cheng Wang, Accelerating development of PV power generation to guarantee the sustainable development of China's energy resources, Engineering Sciences (9), 51-63(2011).

[4] Liu, L.Q., Wang, Z.X., Zhang, H.Q, Solar energy development in China-a review, Renew Sustain Energy Rev 14,301-311(2010).

[5] Li, Z.S., Zhang, G.Q., Li, D.M, Application and development of solar energy in building industry and its prospects in China, Energy Policy 35, 2127-2141(2007).

[6] Zhang, P.D., Yang, Y.L., Zheng, Y.H, Opportunities and challenges for renewable energy policy in China, Renew Sustain Energy Rev 13(2), 439-449(2009).

[7] Zhi, Q., Sun, H., Li, Y., Xu, China's solar PV policy: an analysis based on policy instruments, Applied Energy 12(9), 308-319(2014).

[8] Fang Zhang, Hao Deng, Robert Margolis, Jun Su, Analysis of distributed-generation photovoltaic deployment, installation time and cost, market barriers, and policies in China, Energy Policy 81, 43-55(2015).

[9] Zhang, S.F., Andrew-Speed, P., Ji, M.Y, The erratic path of the low-carbon transition in China: Evolution of solar PV policy, Energy Policy 67, 903-912(2014).

[10] Xie, D, Solar power stations have encountered "water crisis". Southern Weekly. http://www.infzm.com/content/103427.

[11] Junfeng Li, Studies on investment and financing mechanism that support the development of China's distributed solar PV industry[R], Beijing, 2014.

[12] S.M. Moosavian, N.A. Rahim, J. Selvaraj, K.H. Solangi, Energy policy to promote photovoltaic generation, Renew Sustain Energy Rev 25, 44-58(2013).

[13] S. Avril, C. Mansilla, M.Busson, T.Lemaire, Photovoltaic energy policy: Financial estimation and performance comparison of the public support in five representative countries, Energy Policy 51, 244-258(2012).

[14] Ekins P, Step changes for decarbonizing the energy system: research needs for renewable, energy efficiency and nuclear power, Energy Policy 32, 1891-1904(2004).

[15] Gang Niu, Overview of distributed generation policies, Power Energy 35, 12-18(2014).

[16] Yuzhi Zhu, Haibin Sun, Guorong Li, PV power generation policy tools and the government's choice: based on the comparative study of Germany, Japan and China, Ecol Econ 8, 128-132(2011).

[17] Lin Jiang, Research on domestic and overseas grid integration policies of distributed PV power generation, Jiangsu Electr Eng 32, 66-68(2013).

[18] Qiong Wu, Hongbo Ren, Weijun Gao, Economic assessment of residential PV system based on dynamic load characteristics, Renew Energy Rev 32, 133-137(2014).

[19] Haitao Huang, Qunyin Guo, International experiences of distributed PV FIT and its enlightenment to China, Solar Energy (14), 1-4(2014).

[20] Xiangan Meng, China's PV power generation: market and policies, Power Syst Clean Energy 27, 1-3(2011).

[21] Jannuzzi Gilberto de Martino, de Melo Conrado Augustus, Grid-connected PV in Brazil: policies and potential impacts for 2030, Energy Sustain Rev 17, 40-46(2013).

[22] Antonio, Campíneez-Romero Severo, Perez-Molina Clara, Castro-Gil Manuel, Profitability analysis of grid-connected PV facilities for household electricity self-sufficiency, Energy Policy 51, 749-764(2012).

[23] Lihua Lin, Ruimin Zhu, Meiping Huang, The economic benefits of distributed PV power generation, Mod Prop Manag 13, 42-43(2014).

[24] Pillai Gobind G, Putrus Ghanim A, Georgitsioti Tatiani, et al., Near-term economic benefits from grid-connected residential PV systems, Energy 68, 843-843(2014).

[25] He Huang, Financial analysis of distributed PV power generation project of family, Anhui Electr Eng Prof Tech Coll 19, 72-77(2014).

[26] Fengjun Xiao, Economic dispatch of distributed photovoltaic power generation systems, Technol Enterp (1), 185-186(2014). 
[27] Qiang Jin, Zinan Shi, Jingru Li, National economic evaluation of PV generation, Electr Power Constr 34, 87-90(2013).

[28] Guanghua Jiao, Feasibility study of solar distributed PV project on rooftop, Inn Mong Coal Econ (5), 7-8(2014).

[29] Xingang Zhao, Yiping Zeng, Di Zhao, Distributed solar PV in China: Policies and economic performance, Energy 82, 1-12(2015).

[30] Chuntian Cheng, BenxiLiu, Kwok-WingChau, China's small hydropower and its dispatching management, Renew Sustain Energy Rev 42, 43-55(2015).

[31] Gao Ciwei, Li Yang, Evolution of China's power dispatch principle and the new energy saving power dispatch Policy, Energy Policy 38, 7346-7357(2010).

[32] Jiahai Yuan, Xu Yan, Managing electric power system transition in China, Renew Sustain Energy Rev 16, 5660-5677(2012).

[33] Jiahai Yuan, Shenghui Sun, Wenhua Zhang, The economy of distributed PV in China, Energy 78, 939-949(2014).

[34] Sun Hongxiang, An overview and research of China's PV Industry policies based on worldwide comparison, Technology and Innovation Management 35(3), 230-237(2015).

[35] Sufang Zhang. Analysis of DSPV (distributed solar PV) power policy in China. Energy 98, 92-100(2016).

[36] Sufang Zhang. Innovative business models and financing mechanisms for distributed solar PV deployment in China. Energy Policy 95, 458-467(2016).

[37] Frauke Urban, Sam Geall, Yu Wang, Renewable and Sustainable Energy Reviews 64, 531-542(2016).

[38] Ping Huang Simona O. Negro, Marko P. Hekkert, Kexin Bi, How China became a leader in solar PV: An innovation system Analysis. Renewable and Sustainable Energy Reviews 64, 777-789(2016).

[39] Zhong-ying Wang, Report on the development of China's renewable energy industry 2011, China Chemical Industry Press, Beijing, 2012.

[40] Morthorst, P.E, Policy instruments for regulating the development of wind power in a liberated electricity market. Riso National Laboratory, Roskilde, Denmark, 1999.

[41] Haas, R., Efficiency and effectiveness of promotion systems for electricity generation from renewable energy sources--lessons from EU countries, Energy 36, 2186-2193(2011).

[42] Judith Lipp, Lessons for effective renewable electricity policy from Denmark, Germany and the United Kingdom, Energy Policy 35, 5481-5495(2007).

[43] Su-fang Zhang, Interactions between renewable energy policy and renewable energy industrial policy: a critical analysis of China's policy approach to renewable energies, Energy Policy 62, 342-353(2013).

[44] Haas, R., How to promote renewable energy systems successfully and effectively, Energy Policy 32, 833-839(2004).

[45] Zhong-ying Wang, Report on the development of China's renewable energy industry 2012, China Chemical Industry Press, Beijing, 2013.

[46] Zheng Hu, Review of wind power tariff policies in China, Energy Policy 53, 41-50(2013).

[47] China Institute of Energy Economics Research, Compilation of policies regarding renewable energy in China, Economy \& Management Publishing House, Beijing, 2012.

[48] Li-hongYi, Yi-hong Yu, Evaluating on the policy system of PV industry: multi-levels or diversification, Reform (8), 114-124(2012).

[49] Chang-gui Wang, Da-cheng $\mathrm{Wu}$, The Golden-Sun program plays an undeniable role in kicking off China's PV market, Solar Energy (16), 18-26(2013).

[50] Yue Zhu, Assessment of the Golden-Sun program, Finance (5), 72-80(2013).

[51] The Hydropower Design Institute of China, Fruits of construction of China's solar energy power generation 2012, China Water Power Press, Beijing, 2013.

[52] Jun-feng Li, Si-cheng Wang, Report on China's PV development 2013, Economy \& 
Management Publishing House, Beijing, 2013.

[53] Qinghai Science \&Technology Departmen, Golden-Sun demonstration projects implemented in Qinghai produce notable results(in Chinese). http://www.most.gov.cn/dfkj/qh/zxdt/201303 /t20130312_100096.html.

[54] Dan Shi, Review of energy economics theory and policy research, Economy \& Management Publishing House, Beijing, 2012.

[55] Li-juan Han, Unsmooth grid connection under the Golden-Sun program. http://pv.ally.net.cn/s pecial/2013/0716/1589.html. 